\title{
Międzygeneracyjna transmisja wartości w firmach rodzinnych w kontekście sukcesji
}

\section{Wstęp}

hociaż zainteresowanie badaczy firmami rodzinnymi sięga końca lat sześćdziesiątych XX w. ${ }^{1}$, to szczególna koncentracja działalności badawczej, która nastąpiła w ciągu ostatnich trzech dekad, doprowadziła do wykształcenia się interdyscyplinarnej przestrzeni naukowej. W czasopismach specjalizujących się $\mathrm{w}$ tematyce firm rodzinnych regularnie ukazują się artykuły poświęcone specyfice zarządzania, strategii, ekonomii oraz kwestiom prawnym, a nawet psychologicznym i socjologicznym. Ukazują one zarówno charakterystykę firm rodzinnych, jak i wyzwań, z którymi muszą się one mierzyć.

Nie wnikając w spory wokół definicji firmy rodzinnej, można przyjąć, iż odwołują się one głównie do kwestii własności i zarządzania (i w tych obszarach wytyczają granice jej zakresu pojęciowego $)^{2}$. W literaturze przedmiotu pojawia się jednak jeszcze jeden ważny aspekt: ciągłości istnienia przedsiębiorstwa jako trzeci wymiar definicyjny firm rodzinnych ${ }^{3}$. Jak zauważa Andrzej Blikle, ich

* Dr Łukasz Trembaczowski - Instytut Socjologii, Uniwersytet Śląski w Katowicach, e-mail: lukasz.trembaczowski@us.edu.pl; ORCID: 0000-0002-8914-3811.

1 A.S. Maciel, M.I. de la Garza Ramos, J.L. Esparza Aguilar, J.M. San Martin Reyna, The Influence of Family Relationships in the Succession, "Journal of Family Business Management” 2015, t. 5, nr 2, s. 241.

2 A. Surdej, K. Wach, Przedsiębiorstwa rodzinne wobec wyzwań sukcesji, Difin, Warszawa 2010, s. 12 n.; por. także: Ł. Sułkowski, Organizacja a rodzina. Więzi rodzinne w życiu gospodarczym, TNOiK „Dom Organizatora”, Toruń 2004, s. 9-10.

3 E. Miller, A. Rice, Systems and Organizations, Travistock Publications, London 1967; N. Churchill, K. Hatten, Non-Market-Based Transfers of Wealth and Power. A Research Framework for Family Businesses, „American Journal of Small Business” 1987, t. 11, nr 3, s. 51-64; J. Ward, The Special Role of Straitening Planning for Family Businesses, „Family Business Review” 1988, t. 1, nr 2, s. 105-117; C. Daily, S. Thompson, Ownerships Structure, Strategic Posture, and Firm Growth. An Empirical Examination, 
celem nie jest zysk, „celem jest trwanie”. Tym samym przyjęło się definiowanie firm rodzinnych poprzez odwołanie do trzech wymiarów: własności, zarządu i ciągłości ${ }^{5}$. Ich trwanie wiąże się z jednym $z$ największych wyzwań, przed jakim stają: sukcesją. Powodzenie sukcesji w takich przedsiębiorstwach jest ograniczone. Przyjmuje się, że z pierwszego do drugiego pokolenia zostanie przekazanych 30\% firm, z drugiego do trzeciego zaś $10 \%{ }^{6}$. Zdaniem niektórych autorów definicji firm rodzinnych nie sposób ograniczyć wyłącznie do kryteriów obiektywnych i konieczne jest uwzględnienie czynników subiektywnych typu: wartości, postawy, odpowiedzialność za firmę, zaangażowanie w biznes oraz planowanie sukcesji ${ }^{7}$. Tak więc sukcesja, nie tylko dokonana, lecz także planowana, jest jednym z elementów konstytutywnych dla tych przedsiębiorstw zarówno pod względem kryteriów definicyjnych, jak i perspektywy czasowej.

Znaczenie procesu sukcesyjnego jest dobrze rozpoznane w literaturze przedmiotu, choć większy nacisk kładzie się na uwarunkowania niż skutki ${ }^{8}$. W badaniach zdecydowanie więcej uwagi poświęca się źródłom sukcesu sukcesji ${ }^{9}$. Wśród czynników wpływających na powodzenie procesu sukcesyjnego wskazuje się: chęć przejęcia firmy przez sukcesora, pozytywną relację między nestorem a sukcesorem, przygotowanie sukcesora do przejęcia firmy i jej rentownośćc ${ }^{10}$. Zestaw czynników wpływających na powodzenie procesu sukcesyjnego jest jednak szerszy, ponieważ obejmuje czynniki ekonomiczne, psychologiczne, prawne i podatkowe ${ }^{11}$. Krzysztof Safin (wraz ze współpracownikami) zaproponował sześć kategorii czynników sukcesu procesu sukcesyjnego: czynniki motywacyjne

„Family Business Review” 1994, t. 7, nr 3, s. 237-249; J. Barnach, J. Granitsky, Successful Succession in Family Business, „Family Business Review” 1995, t. 8, nr 2, s. 131-155.

${ }^{4}$ L. Sułkowski, A. Marjański, Firmy rodzinne. Jak osiagnaćć sukces $w$ sztafecie pokoleń, Wydawnictwo Poltext, Warszawa 2009, s. 37.

5 W. Handler, Methodological Issues and Considerations in Studying Family Business, „Journal of the Family Firm Institute" 1989, t. 2, nr 3, s. 257-276; P. Sharma, J. Christman, J. Chua, Strategic Management of the Family Business. Past Research and Future Challenges, „Family Business Review” 1997, t. 10, nr 1, s. 1-35; J. Chua, J. Christman, P. Sharma, Defining the Family Business by Behavior. Entrepreneurship, „Theory and Practice” 1999, t. 23, nr 4, s. 19-39.

${ }^{6}$ A. Lewandowska, Kody wartości czyli jak skutecznie przejść sukcesję w firmie rodzinnej, Lewandowska i Partnerzy, Poznań 2015, s. 84. Por. także Q.J. Fleming, Tajniki przetrwania firmy rodzinnej, tłum. C. Matkowski, Helion, Gliwice 2006, s. 8.

A. Marjański, Specyfika firm rodzinnych, w: Firma w rodzinie, czy rodzina w firmie. Metodologia wsparcia firm rodzinnych, Polska Agencja Rozwoju Przedsiębiorczości, Warszawa 2012, s. 30.

8 P. Sharma, J. Christman, J. Chua, Strategic management..., s. 7.

9 J. Barnach, J. Granitsky, Successful succession...

10 E. Venter, C. Boshoff, G. Maas, The Influence of Successor Related Factors on the Succession Process in Small and Medium Sized Family Businesses, „Family Business Review” 2005, t. 18, nr 2, s. 283-303.

${ }_{11}$ H. Bienert, D. Eberhardt, R. Hofmann, A. Müller, Entscheidungsprozesse in der Unternehmensnachfolge im Familienunternehmen - ein Prozessmodell, Forschungsbericht, KTI Nr 8555, 2008, https://digitalcollection.zhaw.ch/bitstream/11475/17110/2/Make\%20it\%20easier\%20to\%20invest_2008_ SC3.2.pdf (dostęp: 1.10.2021). 
sukcesora i nestora, poziom kompetencji sukcesora, harmonia w rodzinie, sytuacja przedsiębiorstwa oraz relacje sukcesora $\mathrm{z}$ pracownikami ${ }^{12}$. Jednocześnie w koncentrycznym schemacie czynników wpływających na sukcesję autorzy ci wskazują na wartości jako sferę centralną, najbliższą procesowi sukcesji ${ }^{13}$.

Znaczenie wartości w firmach rodzinnych jest trudne do przecenienia, gdyż stanowi o ich charakterystyce. Przy czym za najważniejsze dla funkcjonowania i spójności działań przedsiębiorstwa uważa się wartości założyciela ${ }^{14}$. Rozumienie wartości w literaturze przedmiotu jest bardzo zróżnicowane. Często są one sprowadzane do wartości społeczno-emocjonalnych ${ }^{15}$, wpisujących się w szerszy zakres pozamaterialnych składników wartości firmy. W perspektywie socjologicznej, przyjętej w niniejszym tekście, wartości są traktowane jako przekonania: „Wartości pojmowane jako cele działań funkcjonują w świadomości jednostek i są traktowane jako przekonania potencjalne, uruchamiane i aktualizowane w adekwatnych sytuacjach i kontekstach, kiedy pojawiają się odpowiednie racje, motywacje czy wyzwania"16.

W polskiej literaturze odniesienia do transmisji wartości obejmują: sukcesję, priorytety, identyfikację rodziny z firmą oraz związki emocjonalne między członkami rodziny ${ }^{17}$.

Modele znaczenia wartości w przedsiębiorstwie rodzinnym w polskiej literaturze przedmiotu przyjmują postać przenikających się systemów. W najprostszym ujęciu są nimi: rodzina i firma ${ }^{18}$. Zgodnie $\mathrm{z}$ tym modelem możliwe jest wyodrębnienie kategorii wartości rodziny i wartości firmy, które w praktyce firm rodzinnych znacząco się przenikają. Adrianna Lewandowska w swojej koncepcji wskazuje na możliwość ustalenia kluczowych wartości firmy rodzinnej w obszarze nakładania się wartości rodzinnych (rozumianych jako wartości założyciela),

${ }_{12}$ K. Safin, J. Pluta, B. Pabjan, Strategie sukcesyjne polskich przedsiębiorstw rodzinnych, Difin, Warszawa 2014, s. 48.

13 Tamże, s. 48-49.

14 A. Lewandowska, J. Lipiec, Konstytucje firm rodzinnych. W kierunku długowieczności, Oficyna a Wolters Kluwer business, Warszawa 2015, s. 84.

15 L.R. Gomez-Mejia, K. Haynes, M. Nunez-Nickel, K. Jacobson, J. Moyano-Fuentes, Socioemotional Wealth and Business Risks in Family Controlled Firms. Evidence from Spanish Olive Oil Mills, „Administrative Science Quarterly” 2007, t. 52, nr 1, s. 110.

16 J. Szymczyk, Socjologiczne rozumienie wartości w aspekcie relacjonistycznym, „Zeszyty Naukowe KUL" 2019, t. 62, nr 3, s. 36. Por. także M. Misztal, Problematyka wartości w socjologii, PWN, Warszawa 1980, s. 62-63.

17 R. Zajkowski, Transfery władzy, własności i wartości w przedsiębiorstwach rodzinnych. Efekt drugiego pokolenia, Wydawnictwo C.H. Beck, Warszawa 2018, s. 188.

${ }_{18}$ J. Jeżak, Przedsiębiorczość rodzinna na świecie - rola i znaczenie oraz cech specyficzne, w: Przedsiębiorstwa rodzinne w Polsce. Znaczenie ekonomiczne oraz strategiczne problemy rozwoju, red. J. Jeżak, Wydawnictwo Uniwersytetu Łódzkiego, Łódź 2014, s. 18. 
firmy i pracowników ${ }^{19}$. Model kształtowania i realizowania wartości w firmie rodzinnej, zaproponowany przez Ewę Wiencek-Jankę, również opiera się na trzech systemach i obejmuje obszar wspólny wartości przedsiębiorstwa, firmy $\mathrm{i}$ jednostki ${ }^{20}$. Na podstawie tego modelu w swoich badaniach zidentyfikowała zespoły wartości, występujące w każdym z jego podsystemów. Cechą tych ujęć jest traktowanie wartości firmy rodzinnej jako obszaru wartości wspólnych dla różnych podsystemów, przy ich jednoczesnym rozdzieleniu analitycznym i traktowaniu jako zbiorów tylko częściowo zbieżnych.

Przyjęte w omówionych modelach wartości poszczególnych podsystemów, a zwłaszcza firmy i rodziny, mają charakter wartości grupowych ${ }^{21}$. W swojej koncepcji E. Więcek-Janka traktuje wartości jednostki jako element systemu obok wartości rodzinnych i firmowych. W jej badaniach wartości jednostki i rodziny, traktowane rozłącznie, odnoszą się do rozdzielenia orientacji jednostki na siebie i swoje cele oraz na wspólnotę rodzinną i jej cele. Natomiast A. Lewandowska traktuje wartości rodzinne łącznie z wartościami założyciela, nie czyniąc między nimi rozróżnienia i uznając te ostatnie za kluczowe dla funkcjonowania firmy ${ }^{22}$. W teorii socjologicznej można wyróżnić podejście relacyjne do wartości, które łączy podmiotowo-indywidualny charakter wartości ze społecznym profilem kategorii aksjologicznych ${ }^{23}$. Przyjęcie takiej perspektywy pozwala na spojrzenie na wartości rodzinne i firmowe (traktowane dotąd jak osobne podsystemy) w sposób kompleksowy poprzez odczuwanie i uznawanie ich przez jednostki łączące te dwa podsystemy, czyli nestorów i sukcesorów. Jednocześnie stawia w centrum problem międzypokoleniowej transmisji wartości w rodzinie, gdyż sukcesorzy mogą przyjmować kontekst rodzinny za układ odniesienia w sferze wartości.

\section{Założenia teoretyczne i problem}

Podbudowę teoretyczną niniejszego opracowania stanowiły: koncepcja konstruktywizmu strukturalnego Pierrea Bourdieu oraz granic symbolicznych Michele Lamont ${ }^{24}$. Badaczka, przyjmując perspektywę teoretyczną francuskiego

19 A. Lewandowska, Identyfikacja kluczowych wartości jako istotny element konkurowania firm rodzinnych, w: Zarzadzanie w XXI wieku. Koncepcje, trendy, problemy, red. B. Godziszewski, B. Kołosowska, J. Szołno-Koguc, Wyższa Szkoła Bankowa, Toruń 2009, s. 181.

20 E. Więcek-Janka, Wiodące wartości w zarządzaniu firmami rodzinnymi, Wydawnictwo Politechniki Poznańskiej, Poznań 2013, s. 245.

${ }^{21}$ Por. M. Misztal, Problematyka wartości w socjologii.., s. 37.

22 A. Lewandowska, Identyfikacja kluczowych..., s. 180.

23 J. Szymczyk, Socjologiczne rozumienie..., s. 38.

${ }_{24}$ M. Lamont, The Dignity of Working Man. Morality and the Boundaries of Race, Class and Immigration, Russell Sage Foundation, New York 2000; taż, Money, Morals and Manners. The Culture of the French and American Upper-Middle Class, The University of Chicago Press, Chicago-Londyn 1992. 
socjologa, dokonuje jej przebudowy, wskazując na znaczenie szerszego kontekstu społeczno-kulturowego, swoistych repertuarów kulturowych, z których działające jednostki mogą czerpać elementy dyferencjacji grupowej. W swojej koncepcji granic symbolicznych autorka wyróżniła pięć kryteriów oceniania, którymi posługują się członkowie grup, wyznaczając wyższość oraz odmienność w stosunku do przedstawicieli innych grup. Są to: właściwości kulturowe, poziom intelektualny, wyższość moralna, bogactwo i etniczność. Zwiększyła tym samym zakres kryteriów dystynkcji proponowanych przez P. Bourdieu, w szczególności poszerzając obszar symbolicznego zróżnicowania poza kapitał kulturowy i wskazując w swoich pismach na wagę kryterium moralnego jako czynnika odróżniającego jedne grupy od drugich. Jak twierdzi: „(...) pomimo przyjmowania przez każdą z grup swoich zasad moralnych jako uniwersalnych, każda uprzywilejowuje bardzo odmienne aspekty moralności, odnośnie do tego co wyróżnia inną grupę"25.

W tym ujęciu wymiar aksjonormatywny jest potraktowany nie tylko jako czynnik tożsamości grupowej, lecz także mechanizm budowania dystansu wobec grup odmiennych. Taka perspektywa teoretyczna pozwala na nowe ujęcie problematyki wartości firmy rodzinnej. W literaturze przedmiotu bowiem wartości firmy rodzinnej są traktowane jako jej specyficzny zasób lub czynnik konstytutywny $^{26}$. Tym samym konotują jednoznacznie pozytywnie. Czasem, z racji wartości, którymi się kierują, firmy rodzinne przeciwstawiane są korporacjom, gdzie najwyższą (o ile nie jedyną) wartością jest zysk akcjonariuszy. Przyjęcie za M. Lamont sfery aksjonormatywnej jako czynnika budowania dystynkcji pozwala na spojrzenie na wartości firmy rodzinnej w sposób bardziej złożony niż dotychczas oraz zrozumienie procesu, w jakim przedstawiciele firmy rodzinnej posługują się wartościami dla budowy własnej tożsamości.

Kształtowanie się habitusu pierwotnego jednostek jest ważnym czynnikiem reprodukcji pozycji społecznych w kolejnych pokoleniach. Habitusy, w koncepcji P. Bourdieu, są ustrukturyzowane i strukturujace ${ }^{27}$, a elementem owej strukturacji jest naturalizacja porządku społecznego odbywająca się poprzez przemoc symboliczną wpisaną $\mathrm{w}$ działanie pedagogiczne ${ }^{28}$. „Czym zatem jest przemoc symboliczna? Polega ona na transmisji wzorców zachowań, znaków

${ }_{25}$ M. Lamont, Culture and Identity, w: Handbook of Sociological Theory, red. J.H. Turner, Kluwe Academia/Planum Publishers, New York 2001, s. 178 (tłumaczenie własne).

26 J. Jeżak, W. Popczyk, A. Winnicka-Popczyk, Przedsiębiorstwo rodzinne. Funkcjonowanie i rozwój, Difin, Warszawa 2004, s. 23 n.

27 P. Bourdieu, Szkic teorii praktyki. Poprzedzony trzema studiami na temat etnologii Kabylów, tłum. W. Kroker, Wydawnictwo Marek Derewiecki, Kęty 2007, s. 192-193.

${ }_{28}$ P. Bourdieu, J.C. Passeron, Reprodukcja. Elementy teorii systemu nauczania, tłum. E. Neyman, Wydawnictwo Naukowe PWN, Warszawa 2006, s. 72 n. 
i treści danej kultury wraz z narzucaniem ich interpretacji”29. Zdaniem Agnieszki Suchockiej każde działanie pedagogiczne nosi cechy przemocy symbolicznej poprzez narzucenie arbitralności kulturowej, której podstawą są układy sił pomiędzy klasami (grupami) ${ }^{30}$. Dlatego też wychowanie rodzinne stanowi nie tylko element kształtowania się habitusów, lecz także reprodukcji międzypokoleniowej. Przy czym wartości i wartościowanie są nieodwołalnie wplecione w proces wychowania, gdyż „...) nie da się sensownie myśleć o wychowaniu poza wartościami” ${ }^{31}$. Międzypokoleniowa transmisja wartości zdaniem Hanny Elżanowskiej „(...) jest mechanizmem, który ukazuje ciągłość pokoleniową w zakresie przejawianych wartości (czyli wskazuje na podobieństwo między rodzicami a dziećmi)" ${ }^{32}$. Przyglądając się transmisji wartości w rodzinie z perspektywy budowania odmienności i tożsamości firmy rodzinnej, warto przywołać koncepcję „matryc rodzicielskich”, wyznaczających ramy poznania i wartości dla dziecka ${ }^{33}$. W takim ujęciu istotnym problemem staje się poznanie, czy transmisja wartości jest kanałem, poprzez który wartości właściciela-założyciela oddziałują na przedsiębiorstwo rodzinne nawet po jego ustąpieniu. „Wychowanie sukcesora do zarządzania rodzinnym przedsięwzięciem i wpojenie mu podstawowych wartości może warunkować jego przyszłe zachowania i postępowanie w biznesie" ${ }^{\prime 3}$. Internalizacja wartości następuje poprzez działania wychowawcze i pedagogiczne w pierwotnej socjalizacji. Międzypokoleniowa transmisja wartości oznaczałaby więc istnienie podobieństwa pomiędzy wartościami przedstawicieli obu pokoleń kierujących firmą rodzinną.

Opierając się na przyjętych założeniach teoretycznych, postawiono następujące pytania badawcze:

- Jakie wartości rodziny i firmy cenią nestorzy, a jakie sukcesorzy?

- Czy w przypadku nestorów i sukcesorów w firmach rodzinnych można mówić o międzypokoleniowej transmisji wartości?

- Jakie są podobieństwa i różnice między wartościami rodzinnymi a firmowymi wskazywanymi przez badanych?

29 A. Suchocka, Przemoc symboliczna jako element ukrytego programu kształcenia polskiej szkoły, „Zeszyty Naukowe Akademii Marynarki Wojennej” 2011, R. 52, nr 4 (187), s. 294.

30 Tamże.

31 R. Skrzypniak, Transmisja międzypokoleniowa wartości wychowawczych w rodzinie, Rodzina w czasach szybkich przemian, „Roczniki Socjologii Rodziny” 2001, t. 13, s. 150.

${ }^{32} \mathrm{H}$. Elżanowska, Międzypokoleniowa transmisja wartości w rodzinie, w: Studia z Psychologii w Katolickim Uniwersytecie Lubelskim, t. 18, red. O. Gorbaniuk, B. Kostrubiec-Wojtachnio, D. Musiał, M. Wiechetek, Wydawnictwo KUL, Lublin 2012, s. 107.

33 M. Ziółkowski, Znaczenie, interakcja, rozumienie. Studium z symbolicznego interakcjonizmu i socjologii fenomenologicznej jako wersji socjologii humanistycznej, PWN, Warszawa 1981, s. 232-233. Za: H. Elżanowska: Międzypokoleniowa transmisja..., s. 100.

${ }^{34}$ M. Krajewska-Nieckarz, Transfer wartości w procesie sukcesji firmy rodzinnej „Przedsiębiorczość i Zarządzanie", 2016, t. 17, z. 6, s. 117. 
Bazując na relacyjnym podejściu do wartości oraz traktowaniu rodziny i firmy jako podsystemów modelu przedsiębiorstwa rodzinnego, postawiono pytanie o podobieństwa i różnice między wartościami rodziny i firmy ${ }^{35}$. Opierając się na koncepcji transmisji wartości w procesie sukcesyjnym, zapytano o powtarzanie się wartości przedstawicieli obu pokoleń oraz zachodzenie transmisji wartości. Próbując na nie odpowiedzieć, dokonano zestawienia wartości deklarowanych przez przedstawicieli obu pokoleń zarządzających firmami rodzinnymi oraz przeanalizowano ich wpływ na powodzenie procesu sukcesji.

\section{Metoda badań}

Wyniki badań omawiane w niniejszym artykule stanowią część szerzej zakrojonego projektu badawczego. Materiał poddany analizie został zgromadzony w ramach pilotażu badań realizowanego w latach 2016-2017 na terenie pięciu województw. Badania główne w 2020 r. przerwała pandemia, która dotknęła zarówno rodziny, jak i ich firmy.

Wcześniejsze badania procesów sukcesyjnych - w Polsce i na świecie - opierały się głównie na perspektywie właścicielskiej ${ }^{36}$. Realizacja celów poznawczych niniejszego projektu wymagała jednak poznania perspektywy obu stron procesu. Dlatego też w badaniach zostały zrealizowane wywiady z nestorami i sukcesorami z tych samych firm rodzinnych. Wywiady te prowadzone były osobno.

Dobór próby miał charakter celowy. Zasadniczym kryterium był wybór firm, w których sukcesja już się dokonała lub była w bardzo zaawansowanej fazie (zarządzanie firmą przeszło w ręce sukcesora). W efekcie wytypowanych zostało dwanaście firm rodzinnych, w których zrealizowano dwadzieścia sześć wywiadów pogłębionych. Ich większa liczba jest spowodowana przeprowadzeniem $\mathrm{w}$ jednej z firm rozmów $\mathrm{z}$ obojgiem nestorów i sukcesorów (ze względu na rozbieżność perspektyw nestorów). Wśród nestorów dominowali mężczyźni (tylko jeden wywiad zrealizowano $\mathrm{z}$ nestorką) podobnie jak w przypadku sukcesorów (dwie sukcesorki i jedenastu sukcesorów). Ze względu na brak danych na temat zbiorowości generalnej firm rodzinnych w Polsce nie sposób dokładnie określić, ile z nich jest prowadzonych przez mężczyzn, a ile przez kobiety. Jednakże obserwacje autora poczynione w trakcie licznych spotkań i zjazdów oraz rozmowy z przedstawicielami organizacji zrzeszających firmy

${ }^{35}$ J. Szymczyk, Socjologiczne rozumienie..., s. 38 n.; J. Jeżak, Przedsiębiorczość rodzinna na świecie..., s. 18.

36 A. Surdej, K. Wach, Przedsiębiorstwa rodzinne...; K. Safin, J. Pluta, B. Pabjan, Strategie sukcesyjne...; A. Pawlak, Sukcesja w polskich przedsiębiorstwach rodzinnych, „Przedsiębiorczość i Zarządzanie” 2014, t. 15, nr 7 (1), s. 55-67. 
rodzinne wskazywały na mniejszą liczebność kobiet w pokoleniu nestorów ${ }^{37}$. Częściej też były one współwłaścicielkami (wraz z mężem) niż samodzielnymi właścicielkami firm. Podobne dysproporcje można dostrzec w pokoleniu sukcesorów, gdyż córki rzadko wskazuje się na sukcesorki, szczególnie w sytuacji, kiedy $\mathrm{w}$ danej rodzinie są męscy potomkowie ${ }^{38}$.

W grupie nestorów siedmioro badanych było w wieku 61-70, czworo - 51-60, a dwoje powyżej 70 lat. Sukcesorzy najczęściej mieli od 21 do 30 lat (siedmioro), czworo - 31-40 lat, dwoje - powyżej 40 lat. Czas trwania sukcesji szacowany jest na ok. 7 lat. Dlatego też stosunkowo rzadkie są sukcesje w okresie wczesnej młodości (najczęściej podyktowane sytuacją zdrowotną nestora), natomiast dość często proces ten jest odkładany w czasie. Do sukcesji dochodzi bowiem dopiero w momencie, kiedy nestor zbliża się do wieku emerytalnego lub już go osiągnie. Biorąc pod uwagę, że dogodny wiek sukcesji bywa określany na ok. 30 lat, różnica wieku pomiędzy nestorem a sukcesorem powinna wynosić ok. 40 lat $^{39}$.

Problemy z kryteriami definicyjnymi dotyczącymi firm rodzinnych mają wpływ na dostęp do zagregowanych danych czy informacji na temat ich szacowanej liczebności. Dlatego też nie przyjęto żadnych dodatkowych założeń selekcyjnych poza pozostawieniem zarówno własności (większościowej), jak $\mathrm{i}$ kierownictwa w ręku rodziny. Wcześniejsze badania wskazywały na brak znaczenia sektora gospodarki dla procesu sukcesji, podobnie jak regionu, w którym była zarejestrowana firma ${ }^{40}$, dlatego też kryteria te nie zostały wykorzystane $\mathrm{w}$ doborze przedsiębiorstw. Respondenci zostali dobrani z województw wielkopolskiego, mazowieckiego, łódzkiego, śląskiego oraz małopolskiego, a kluczem doboru było zaawansowanie procesu sukcesyjnego. Rekrutacja do badań odbywała się w trakcie spotkań i zjazdów firm rodzinnych, a wywiady realizowano w siedzibach przedsiębiorstw. Analiza zgromadzonego materiału wskazuje na znaczenie wielkości ośrodka, w jakim ona funkcjonuje, bowiem różnice pomiędzy firmami rodzinnymi można zaobserwować na linii duże miasta - niewielkie miejscowości. Branża, w której działały przedsiębiorstwa, nie była czynnikiem wpływającym na dobór próby, jednak została wzięta pod uwagę $\mathrm{w}$ analizie materiału. Ujawniła ona, że miała ona znaczenie w takich zjawiskach jak: bariery wejścia nowej konkurencji w sektorze czy procesy konsolidacji (co rzutowało na szanse sprzedaży firmy rodzinnej w sytuacji niepowodzenia procesu sukcesji). Badane firmy funkcjonowały w takich branżach jak turystyka, jubilerstwo, me-

37 Por. A. Surdej, K. Wach, Przedsiębiorstwa rodzinne..., s. 112.

38 K. Safin, J. Pluta, B. Pabjan, Strategie sukcesyjne..., s. 35.

39 A. Surdej, K. Wach, Przedsiębiorstwa rodzinne..., s. 61.

40 K. Safin, J. Pluta, B. Pabjan, Strategie sukcesyjne..., s. 193; A. Surdej, K. Wach, Przedsiębiorstwa rodzinne..., s. 96-135. 
chanika samochodowa, produkcja przemysłowa, budownictwo, ubezpieczenia, tworzenie materiałów wizualnych i filmów, mechanika precyzyjna.

Rozpoznawanie badanego środowiska było czasochłonne i trwało od $2013 \mathrm{r}$. Przedsiębiorcy, w tym również rodzinni, stanowią stosunkowo hermetyczne środowisko, dlatego nawiązanie relacji zajęło autorowi dłuższy czas. Jednakże po kilkukrotnej obecności na zjazdach i spotkaniach Inicjatywy Firm Rodzinnych, które odbywały się w różnych miejscach w kraju, a także na spotkaniach regionalnych oddziałów, udało się nawiązać pozytywne relacje z częścią przedstawicieli środowiska, poznać rodziny i na tej bazie wytypować firmy, w których sukcesja faktycznie się dokonała. Respondentów pozyskiwano także na konferencjach i warsztatach realizowanych przez Instytut Biznesu Rodzinnego. Autor uczestniczył w spotkaniach i poznawał historie rodzin prowadzących firmy, z których część wzięła później udział w badaniach.

Autor prowadził obserwację uczestniczącą jawną, nie kryjąc swojej roli badacza w trakcie: zjazdów i spotkań firm rodzinnych, towarzyskich spotkań odbywających się w trakcie zjazdów oraz podczas warsztatów organizowanych przez oddziały terenowe organizacji zrzeszającej firmy rodzinne. Celem obserwacji było poznanie przyszłych respondentów, a także próba zrozumienia sposobu rozumowania charakterystycznego dla tych przedsiębiorstw. Obserwacja miała funkcję metody pomocniczej, pozwalającej na przygotowanie badań jakościowych.

Istotnym czynnikiem, który może modyfikować uzyskane wyniki, jest tożsamość firmy rodzinnej. Członkowie rodzin zrzeszonych w stowarzyszeniu firm rodzinnych bardzo często podkreślali swoją rodzinność, a wiele z badanych przedsiębiorstw wykorzystuje ten fakt w budowaniu swojego wizerunku i marki. Poczucie odrębności od innych podmiotów gospodarczych jest często przywoływane $\mathrm{w}$ trakcie wydarzeń, w rozmowach nieformalnych, ale również znalazło odbicie w wywiadach. Przedsiębiorstwa rodzinne, które nie działają w zorganizowanych stowarzyszeniach, mogą nie mieć tak wykształconego poczucia swojej odrębności. Jest to istotne zastrzeżenie w odniesieniu do uzyskanych wyników, ponieważ wartości w badaniu często były przywoływane w kontekście odmienności firmy rodzinnej od pozostałych przedsiębiorstw.

Wielkość firmy była brana pod uwagę $\mathrm{w}$ trakcie przygotowywania badań, gdyż z obserwacji nieformalnych podgrup, na jakie dzieliły się spontanicznie przedsiębiorstwa w trakcie spotkań, wynikało, iż ich wielkość jest ważnym czynnikiem różnicującym. W efekcie zostały zrealizowane wywiady w czterech firmach z każdej grupy: mikro (1-9 pracowników), małych (10-49 pracowników) i średnich (50-249 pracowników). Niemal wszystkie firmy po zakończeniu procesu sukcesji przyjmowały postać spółki (najczęściej spółki cywilnej). Stan prawny własności firmy był regulowany udziałami członków rodziny (zarówno nestorów, jak i sukcesorów). W czterech przedsiębiorstwach proces przekazywa- 
nia własności wciąż czekał na dokończenie. W czterech kolejnych przypadkach zostały wykształcone większe grupy firm połączonych kapitałowo. Rodzina prowadząca działalność biznesową nie musi bowiem zarządzać tylko jednym przedsiębiorstwem. W podanych grupach kapitałowych nestorzy podążali różnymi drogami: zakładając własną nową firmę, jako źródło utrzymania na emeryturze; zakładając nową firmę dla dziecka, które nie odziedziczyło starej; tworząc nową spółkę poprzez połączenie dotychczasowej działalności z nową, założoną w spółce $\mathrm{z}$ jednym $\mathrm{z}$ sukcesorów bądź przekazując dziecku zarząd nad jedną $\mathrm{z}$ firm w ramach całej grupy.

Wywiady zrealizowano za pomocą scenariusza wywiadu, który zawierał pięć bloków pytań. Część z nich była poświęcona problematyce rodziny i wartości. $\mathrm{W}$ analizie prezentowanej w niniejszym artykule wykorzystano wszystkie wypowiedzi zakodowane jako odniesienia do wartości, niezależnie od tego, jakiego pytania dotyczyły odpowiedzi badanych. Szczególnie istotne okazały się pytania o pracę w roli kierującego firmą, gdyż to właśnie w tych wypowiedziach badani wskazywali na wartość, jaką stanowi praca.

Realizacja badań okazała się utrudniona mimo znajomości środowiska. Problemy sukcesji przenikają się z kwestiami życia rodzinnego, majątku firmy i rodziny, a nawet strategii biznesowej. Żaden z tych tematów nie jest chętnie poruszany $\mathrm{w}$ rozmowach $\mathrm{z}$ obcymi osobami, nawet $\mathrm{w}$ roli badaczy. Tylko w części wywiadów udało się uzyskać otwartość wypowiedzi. Respondenci opowiadali wtedy o konfliktach, trudnych relacjach czy żalu wobec rodziców albo współmałżonków. W wywiadach, w których takiej otwartości w relacji z respondentem nie udało się uzyskać, badani niechętnie wypowiadali się na trudne tematy i nie rozwijali takich wątków. Wypowiedzi te były dla części badanych trudne emocjonalnie, gdyż często dotyczyły osobistych przeżyć. Dla niektórych rozmówców był to pierwszy raz, kiedy opowiadali o tym komuś spoza rodziny. Jednocześnie trzeba zaznaczyć, że wiele wywiadów pokazywało bardzo dobre relacje pomiędzy rodzicami i dziećmi, a przebieg sukcesji był przedstawiany jako proces w dużej mierze bezkonfliktowy.

Warunkiem, wynikającym z przyjętej koncepcji badań, były wywiady z nestorem i sukcesorem, co utrudniało ich realizację, gdyż obecność obojga respondentów w firmie w tym samym czasie nie zawsze jest możliwa.

Analiza zgromadzonego materiału opiera się na kodach, którymi opatrzono fragmenty wywiadów. Wykorzystano kombinację kodów ustalonych z góry (np. wartości rodziny, wartości firmy) i kodów wyłaniających się w trakcie badania (np. rodzina jako wartość, firma jako praca) ${ }^{41}$. Posłużono się tu analizą zoriento-

${ }_{41}$ J.W. Creswell, Projektowanie badań naukowych. Metody jakościowe, ilościowe i mieszane, tłum. J. Gilewicz, Wydawnictwo Uniwersytetu Jagiellońskiego, Kraków 2013, s. 203. 
waną na znaczenie, bazując na wypowiedziach respondentów w poszczególnych zakodowanych kategoriach ${ }^{42}$.

\section{Wartości w rodzinie}

Analizę zgormadzonego materiału i wnioski z niego płynące poprzedzono kilkoma uwagami dotyczącymi udzielanych odpowiedzi. W badaniach wzięli udział nestorzy oraz sukcesorzy z tych samych firm, jednak informacji na temat wartości dużo częściej i obszerniej udzielali nestorzy. Pytani wprost o cenione wartości, wymieniali ich więcej, niż sukcesorzy, a także często opatrywali przykładami z własnego życia. Kilka firm korzystało również z poradnictwa i pomocy zewnętrznej w procesie sukcesji, $\mathrm{w}$ rozwiązaniu problemów związanych z tym procesem. Elementem takich warsztatów była zwykle dyskusja na temat wartości, która pozwalała na ich łatwe przywołanie w trakcie wywiadu. Nie oznacza to jednak, iż pozostałe rodziny miały problem z przywołaniem wartości, którymi się kierują, a jedynie trudniejsze było ich nazwanie, często były opisywane na dość ogólnym i abstrakcyjnym poziomie.

Badani pytani expressis verbis o wartości rodzinne i firmowe, niemal nigdy nie dokonywali ich rozróżnienia. Niezależnie od tego, które pytanie - o wartości firmy czy o wartości rodzinne - zadawano najpierw, respondenci wskazywali na tożsamość ich zakresów. Co więcej, zdarzały się odpowiedzi dotyczące wartości rodzinnych w przypadku zadanego pytania o wartości firmowe. Dopytywanie o różnice między tymi wartościami budziło raczej zdziwienie, a czasem wyrażone wprost utożsamienie wartości rodzinnych i firmowych:

(...) myślę, że bardzo porównywalne są te wartości, nie można tak w jednym momencie zupełnie inaczej żyć, zachować i podchodzić do rzeczy, a w drugim zupełnie inaczej (N10).

Utożsamieniu wartości rodzinnych i firmowych sprzyjało przekonanie, iż

\section{(...) firma to jest jak rodzina, tylko większa (N13).}

Interesujący jest brak refleksji u wszystkich rozmówców nad potencjalną rozbieżnością pomiędzy wartościami firmy a wartościami wyznawanymi przez pracowników zatrudnionych w tych firmach. Te, do których się odwoływali, badani traktowali jako uniwersalne, powszechnie akceptowane. Jednocześnie

42 S. Kvale, Prowadzenie wywiadów, tłum. A. Dziuban, Wydawnictwo Naukowe PWN, Warszawa 2010, s. 171-172. 
w odpowiedziach na pytania odnoszące się do pracowników pojawiały się wskazania na znaczenie wartości przy rekrutacji pracownika:

(...) czy on pasowałby do firmy, swoją postawą, swoją osobą, swoimi przeżyciami, nawet nie przeżyciami, ale wartościami (S11).

Mimo niedostrzegania różnic przez samych badanych analiza ujawnia jednak pewne odmienności w podejściu do wartości rodzinnych i firmowych. Polegają one z jednej strony na traktowaniu rodziny jako wartości, a z drugiej - na wskazywaniu wartości firmowych, które będąc pochodną wartości rodzinnych, są jednak w firmie odmiennie realizowane.

W celu wskazania tych różnic konieczne jest omówienie wartości najważniejszych i najczęściej powracających w wywiadach. Badani przywołali w nich trzydzieści trzy różne wartości: niezależność, patriotyzm, prospołeczność, dekalog, szacunek, uczciwość, rzetelność, gotowość do pomocy, dialog, zaufanie, rodzina, wartości chrześcijańskie, lojalność, konsekwencja, wiara, poczucie bezpieczeństwa, miłość, zgoda, zrozumienie, praca, sprawiedliwość, punktualność, spokój, rozwaga, poświęcenie, szczerość, zaangażowanie, skromność, samodzielność, prawdomówność, zaradność, zdecydowanie, wytrwałość. Wartości te zostały przywołane w kolejności przypadkowej, jednak częstotliwość ich wskazywania przez respondentów była zróżnicowana, a większość wymieniona wprost tylko jednokrotnie. Analiza ilościowa odpowiedzi nie oddałaby złożoności problematyki, gdyż niektóre z wymienionych wartości występowały często w kontekście, nawet jeśli nie były przywoływane wprost.

Najczęściej wymienianą przez badanych wartością była uczciwość. Wymieniła ją więcej niż połowa badanych, zarówno nestorów, jak i sukcesorów. Rozumienie uczciwości było dwojakie: jako cechy dystynktywnej rodziny oraz jako wymagania wewnątrz firmy. W odniesieniu do pracowników uczciwość była rozumiana jako obowiązująca we wzajemnych relacjach. Z jednej strony badani podkreślali swoją uczciwość w stosunku do pracowników:

tu ja mogę powiedzieć, że za te 28 lat nie było opóźnienia w wypłacaniu pensji, każdy tutaj jest uczciwy (N2),

z drugiej strony oczekiwali uczciwości od swoich pracowników:

(...) gdybym kierował się innymi wartościami, to może bym odpuścił, ale że ludzie wiedzą, jaki jestem, to wolą sami przyjść i się przyznać, jeśli coś nawalą, bo wiedzą, że ja się i tak o tym dowiem (...) człowiek nie jest osobą nieomylną, pomylić się może, ale nie oszukiwać, jak przyjdzie i się przyzna, to okej, nie ma sprawy, ale dla mnie najgorszą sprawą jest, że on ukryje to, to jest nieuczciwe w stosunku do nas (S4). 
Ta wewnątrzfirmowa uczciwość jest bezpośrednio związana z uczciwością wobec otoczenia: klientów, partnerów biznesowych czy społeczności lokalnej. Zachowanie zgodne z tą wartością jest traktowane jako cecha dystynktywna, odróżniająca firmę rodzinną od innych podmiotów rynkowych. Wynik ten jest zbieżny z badaniami granic symbolicznych wśród przedstawicieli klas średnich Stanów Zjednoczonych i Francji, gdzie uczciwość była wiodącą, z czterech wyodrębnionych w badaniu wartości wykorzystywanych w budowaniu moralnych granic $^{43}$. Jednak w przeciwieństwie do wielowymiarowego i zrelatywizowanego rozumienia uczciwości, jak w badaniach $\mathrm{M}$. Lamont, respondenci z firm rodzinnych wskazywali na tradycyjne, wręcz konserwatywne jej pojmowanie:

Kiedyś, w zamierzchłych czasach mówiono o ludziach sprawiedliwych, czyli uczciwych, którzy, idąc przez życie, nie wyrządzają krzywdy (...). Człowiek uczciwy gromadzi wokół siebie ludzi uczciwych (N7).

Jednocześnie uczciwość, jako wartość realizowana w praktyce działalności biznesowej, procentuje wizerunkiem ułatwiającym kooperowanie $\mathrm{z}$ innymi, pozyskiwanie klientów czy wręcz budowanie przewagi rynkowej. Jeden z sukcesorów wskazywał na znaczenie reputacji wypracowanej przez ojca dla realizowania kontraktów:

I są firmy, że jak ja zadzwonię i powiem, że jestem synem Pana X, to mówią, żeby wysłać im na przelew, bo wiedzą, że mogą ufać mojemu ojcu i nigdy nie byli zawiedzeni, jeśli chodzi o jakość i uczciwość (S7).

Taka kapitalizacja wartości jest już dostrzegana w literaturze, a firmy rodzinne są traktowane jako szczególny przypadek, w którym wartości nie mają wyłącznie charakteru abstrakcyjnego, który dopiero trzeba przełożyć na praktykę, lecz są w niej stale obecne ${ }^{44}$.

Jeśli więc potraktować uczciwość jako mechanizm odróżnienia firmy rodzinnej od innych, jej cechę dystynktywną, implikuje to pośrednio założenie o nieuczciwości innych uczestników rynku. Faktycznie, takie postrzeganie rynku, wyniesione z doświadczeń wczesnych lat dziewięćdziesiątych XX w., można odnaleźć w wypowiedziach nestorów odnośnie do genezy i rozwoju firmy. Nie wyklucza się to jednak z traktowaniem uczciwości jako wartości uniwersalnej, której należy przestrzegać, gdyż uniwersalność wartości nie musi być tożsama $\mathrm{z}$ jej powszechnym praktykowaniem ${ }^{45}$.

${ }^{43}$ M. Lamont, Money, Morals..., s. 4.

44 A. Lewandowska, Kody wartości..., s. 58.

${ }_{45}$ Niektórzy nestorzy z satysfakcją mówili o tym, że ich firma przetrwała w przeciwieństwie do firm nieuczciwych konkurentów. 


\section{Rodzina i praca jako wartości}

Dla wielu badanych wartości rodzinne są wręcz utożsamiane z rodziną jako wartością. Rodzina, traktowana jako wartość, pojawia się w wypowiedziach badanych jako naczelna, jedna z najważniejszych w życiu. Wartościami towarzyszącymi takiemu postrzeganiu rodziny były szacunek i religia, czasem wskazywane jednocześnie:

(...) no przede wszystkim jest to rodzina, szacunek dla rodziny, to jest podstawa bez względu na trudności, czasami wydaje się to, że to jest nie do przebycia (...) ja znalazłem odpowiedź na to życie w kościele (N12).

Szacunek przywoływany w kontekście rodzinnym objawiał się zwykle w postaci oczekiwania ojca, iż dzieci oraz żona będą mu go okazywać. Wiązało się to z oczekiwaniem posłuszeństwa (czasem niemal bezwzględnego), co wynikało z wzorców wychowawczych przejętych z rodziny pochodzenia badanego.

My jako dzieci wykonywaliśmy wszystkie prace w domu i pas zawsze wisiał na środku, pas był nietykalny, bo to był pas na nas. On nie był używany często, ale nie mogłem powiedzieć, że czegoś nie zrobię (...) jak ja zwracałem dzieciom uwagę, to małżonka się stawiała, to dla mnie był brak szacunku [który - uzup. Ł.T.] był niedobry dla naszej rodziny (N5).

Takie oczekiwanie szacunku wiązało się z samodzielnym podejmowaniem decyzji dotyczących rodziny przez ojca, komunikowaniem ich i traktowaniem jako niepodważalne, co pozwala na postawienie hipotezy o powiązaniu między traktowaniem szacunku jako istotnej wartości rodzinnej a autorytarnym modelem wychowawczym.

Nie wszystkie jednak przypadki przywoływania szacunku wskazują na takie powiązanie, w wypowiedziach badanych można bowiem dostrzec ujmowanie szacunku jako wartości uniwersalnej, wykraczającej poza krąg rodzinny.

Należy szacunek mieć do każdego i wytłumaczyć, skąd to się bierze (N10).

Istotną wartością rodzinną dla badanych była miłość, która powinna być okazywana dzieciom przez rodziców. Dla respondentów odwołujących się do miłości jako nadrzędnej wartości rodzina stanowiła istotę tak rozumianych uczuć:

Najważniejsze wartości? To miłość do dzieci, miłość do wnuków, nasza wspólna więź rodzinna (N11). 
Rozumienie rodziny jako wartości odwoływało się również do jej funkcji, a w szczególności do nadrzędnej, scalającej system rodzinny, funkcji spójności $^{46}$. Przywołanie rodziny jako wartości nadrzędnej dla rodziny biznesowej pojawiało się w sytuacjach konfliktowych jako mechanizm łagodzący czy wręcz powstrzymujący rodzinę (i firmę) przed rozpadem. Istotne jest podkreślanie wagi więzi między rodzeństwem, która - zdaniem nestorów - jest kluczowa dla zachowania spójności firmy, a rola rodziców, uświadomiona lub nie, polega na stabilizowaniu owej relacji.

Szczególne jest postrzeganie zakresu więzi rodzinnych, gdyż w postawach nestorów przejawia się ujmowanie rodziny w kontekście rodziny nuklearnej: rodzice - dzieci. Paradoksem tego ujęcia jest oczekiwanie od dzieci zachowań odmiennych od relacji, jakie nestorzy mieli z własnym rodzeństwem. W dwóch przypadkach najsilniejszych konfliktów pomiędzy rodzeństwem występujących w procesie sukcesyjnym badani nestorzy odwoływali się do rodziny jako wartości nadrzędnej, która powinna przeważyć interesy własne i egoizm dzieci (zwłaszcza na tle podziału majątku rodzinnego). W obu przypadkach jednak sami nestorzy w trakcie rozwoju firmy byli skonfliktowani z własnym rodzeństwem. Prowadziło to do sytuacji, w której respondent potrafił w niedługim odstępie czasu wypowiedzieć zupełnie sprzeczne twierdzenia:

Najważniejsze na pewno wartości: rodzina, ale trzeba samemu dawać przykład dzieciom (N4), (...) nie chcę mieć nic więcej z rodziną wspólnego, to była moja decyzja, mój błąd (N4),

przy czym pierwsze z nich odnosiło się do nuklearnej rodziny reprodukcyjnej badanego, a drugie do rodziny pochodzenia (w kontekście współpracy w firmie).

Takie nuklearne postrzeganie rodziny tłumaczy również postrzeganie współmałżonków dzieci jako źródła problemu, odpowiedzialnego za konflikty wewnątrz rodziny. Nazywani w środowisku firm rodzinnych „przyczłapkami”"47, współmałżonkowie dzieci są często obarczani odpowiedzialnością za konflikty między rodzeństwem poprzez nadmierne rozbudzanie ambicji i oczekiwań. Co więcej, poradnictwo w tym zakresie wskazuje na konieczność ich wykluczenia ze spotkań na temat sukcesji ${ }^{48}$.

Badanym nestorom zadawano pytanie o stosunek współmałżonków dzieci do firmy. Brak zainteresowania firmą był traktowany jako cecha pozytywna,

46 K. Walęcka-Matyja, Rola ifunkcje rodziny, w: Psychologia rodziny, red. I. Janicka, H. Liberska, Wydawnictwo Naukowe PWN, Warszawa 2014, s. 95-114.

47 Określenie to jest używane wprost na spotkaniach i zjazdach firm rodzinnych, podczas gdy na widowni znajdują się współmałżonkowie dzieci z firm rodzinnych. Określenie ma żartobliwą, ale i pejoratywną konotację.

48 Autor był dwukrotnie świadkiem takich wypowiedzi na warsztatach poświęconych sukcesji. 
„niewtrącanie się”. W przynajmniej jednym przypadku synowa nestora została zwolniona z firmy rodzinnej, co doprowadziło niemal do niepowodzenia procesu sukcesyjnego. W kontekście wartości rodzinnych istotne jest również pomijanie wartości ważnych dla współmałżonków dzieci i traktowanie własnych jako uniwersalnych.

Koncentracja na dzieciach jest szczególnym aspektem wartości rodzinnych przywoływanych przez badanych. Zdaniem Krystyny Slany, „dziecko współcześnie jest dla swoich rodziców (...) bezwartościowe ekonomicznie, ale bezcenne emocjonalnie (oczywiście dla tych, którzy pragną je posiadać), czyli staje się wartością autoteliczną" ${ }^{49}$. W przypadku badanych firm rodzinnych te aspekty - emocjonalny i ekonomiczny - nie są w pełni rozdzielne, wszyscy nestorzy bowiem wskazywali na ukryte bądź jawnie okazywane oczekiwanie, iż dzieci przejmą firmę rodzinną, zwykle znacznie wcześniej niż sukcesorzy zdążyli ową chęć przejęcia firmy wyrazić. Stąd emocjonalny aspekt więzi rodzinnej przeplata się $\mathrm{z}$ ekonomicznym aspektem trwania firmy.

To napięcie dotyka znacznie szerszego problemu relacji między firmą i rodziną, a precyzyjniej - sposobu, w jaki była realizowana przez nestorów rola ojca oraz podziału ról i obowiązków wychowawczych pomiędzy rodzicami. Nieobecność w domu, spowodowana obowiązkami w firmie, była poruszana przez niemal wszystkich nestorów. Podobnie sukcesorzy wskazywali niejednokrotnie na deficyt uwagi i obecności ojca, którego nie widywali poza weekendem. Wypowiedzi świadczące o nawiązaniu dobrej relacji z ojcem dopiero po podjęciu pracy w firmie nie były rzadkością i, jak można wnioskować z reakcji emocjonalnych w trakcie wywiadów, stanowiło to trudny do przepracowania problem.

Obecność firmy rodzinnej w domu lub tuż przy domu, gdzie teren przedsiębiorstwa stanowił naturalny plac zabaw, a pomaganie w firmie ${ }^{50}$ nie różniło specjalnie od innych obowiązków domowych, sprzyjało nawiązaniu dobrych relacji z rodzicami, którzy byli w pobliżu i byli pomocni:

(...) z perspektywy dziecka oceniam to bardzo dobrze, bo on był zawsze dostępny, ja nie wiem, jak on to ogarniał, ale potrafił naprawić mi rower w ciągu dnia, w czasie pracy, a potem coś jeszcze dalej w firmie zrobić (S11).

49 K. Slany, Alternatywne formy życia mał̇̇ńsko-rodzinnego w ponowoczesnym świecie, Zakład Wydawniczy Nomos, Kraków 2003, s. 106.

50 Rozróżnienie pomagania $w$ firmie i pracy $w$ firmie jest ważnym aspektem w opisywanych badaniach: dopiero wejście w ścieżkę sukcesji prowadzi do uznania przez nestora aktywności dziecka za pracę. Dzieci wskazują, że wcześniej zaczęły pracować w firmie, podczas gdy dla rodziców było to nadal pomaganie. Rodzeństwo zaangażowane w firmę, ale nieprzejmujące kierownictwa nadal tylko pomaga. Ważnym czynnikiem różnicującym jest też płeć dziecka, córki bowiem pomagaja, podczas gdy synowie pracują, nawet gdy są podobnie zaangażowani w firmie. 
Jednocześnie sukcesorzy podkreślali, że pracowitość ojca była dla nich wzorem. Choć praca jako wartość została bezpośrednio wskazana tylko raz, to jej znaczenie pojawia się wielokrotnie w kontekście oceny własnego życia zarówno przez nestorów, jak i sukcesorów. Przywołując dwa podejścia do pracy, wyróżnione przez Beatę Łaciak, traktowanej jako źródło dochodów i konieczność albo jako niemal najważniejszą aktywność życiową, wymagającą stałego zaangażowania i wysiłku ${ }^{51}$, bez wątpienia przedsiębiorców rodzinnych można zaliczyć do przedstawicieli tego drugiego podejścia do pracy:

To nie ja mam pracę, a praca ma mnie (N2).

Analizując postrzeganie pracy w rodzinach biznesowych, można dostrzec nakładanie się podziału ról płciowych z klasyfikacją na ludzi pracy i ludzi kariery $^{52}$, gdzie kobietom-matkom przypadła rola skoncentrowana głównie na rodzinie (niemal wszystkie kobiety z badanych rodzin biznesowych pracowały zawodowo ${ }^{53}$ ), a mężczyznom-ojcom rola ludzi kariery, gdzie praca stanowi źródło satysfakcji i podstawowy obszar zaangażowania.

Może za bardzo patrzyło się firma, firma i jeszcze raz ta firma, a ta rodzina, te wartości, czy opieka nad dzieciakami była zawsze drugim planem, zawsze żona się dzieciakami bardziej zajmowała niż ja (N9).

Stąd napięcie pomiędzy wartościami, jakimi są rodzina i praca, doświadczane przez rodziny prowadzące własne firmy zyskuje dodatkowy wymiar, który wpisuje się w relacje rodzinne i małżeńskie.

\section{Transmisja wartości}

Napięcie między wartościami, jakimi są praca i rodzina, jak również nakładającym się na to zróżnicowaniem zaangażowania rodziców w proces wy-

${ }^{51}$ B. Łaciak, Obyczajowość polska czasu transformacji, czyli wojna postu z karnawałem, Wydawnictwo Trio, Warszawa 2005, s. 198.

${ }_{52}$ M. Strykowska, Psychologiczne mechanizmy zawodowego funkcjonowania kobiet, Wydawnictwo Naukowe UAM, Poznań 1992, s. 70. Por. także: J. Ostruch-Kamińska, „Choroba wiecznego prymusa" - rozważania wokól znaczenia pracy zawodowej w rodzinie o równolegtych karierach, w: Rodzina w świecie wartości. Religia, praca i czas wolny, red. W. Muszyński, Wydawnictwo Adam Marszałek Toruń 2010, s. 264-265.

$53 \mathrm{~W}$ jednym przypadku żona nestora zmarła, kiedy sukcesor był małym dzieckiem. Dwie żony nestorów przerwały pracę zawodową na kilka lat w związku z koniecznością poświęcenia się wychowywaniu dzieci. 
chowawczy, stanowi istotny kontekst, w którym rozpatrywać można proces transmisji wartości.

Odbywa się on w środowisku rodzinnym w dwóch obszarach: wzajemnej modyfikacji wartości w relacji małżeńskiej i przekazywaniu wartości dzieciom: bezpośrednio w procesie wychowawczym oraz pośrednio poprzez postawy rodziców względem wartości ${ }^{54}$. Warto jednak podkreślić, że wzajemna modyfikacja wartości małżonków nie jest absolutna nawet w przypadku harmonijnych związków, asymetryczny zaś podział zakresu zadań wychowawczych pomiędzy rodzicami może prowadzić do wystąpienia rozbieżności pomiędzy nestorem i sukcesorem. W przypadku nestorów dochodziło do - zwykle nieuświadamianego - oczekiwania powielenia przez sukcesora znaczenia wartości, jaką stanowi praca (a co za tym idzie firma), przy ograniczonym zaangażowaniu nestora $\mathrm{w}$ proces wychowawczy. Tam, gdzie dzieci były włączone $\mathrm{w}$ działania w firmie już od dzieciństwa, a nestor aktywnie zachęcał je do udziału w pracach $\mathrm{w}$ przedsiębiorstwie, tam proces sukcesji uznawany był za naturalny, a dzieci wręcz niepostrzeżenie włączały się w pracę (pomoc) w firmie.

Czy w przypadku badanych firm rodzinnych twierdzenie o międzypokoleniowej transmisji wartości jest uzasadnione? Posłużenie się metodą liczbowego porównywania wartości wskazywanych przez rodziców i dzieci w celu ustalenia, czy doszło do ich odtworzenia w młodszym pokoleniu, nie przyniosło rozstrzygających efektów ${ }^{55}$. Sukcesorzy wymieniali wiele wartości wspominanych przez nestorów, jak również odwoływali się do innych wartości, których nestorzy nie wspominali. Ilościowe rozstrzygnięcie istniejących podobieństw nie wydaje się tutaj skutecznym rozwiązaniem, gdyż wiele wartości, wymienianych zarówno przez nestorów, jak i sukcesorów, było wskazywanych tylko jednokrotnie. Istotną przesłanką potwierdzającą występowanie międzypokoleniowej transmisji wartości jest powtarzanie się wartości kluczowych, takich jak: uczciwość, rodzina czy szacunek.

Jednocześnie dopiero rozpatrywanie kolejnych par i przypadków pozwala dostrzec podobieństwo wyznawanych wartości, nawet kiedy nie są one werbalizowane. Dobrym przykładem jest sytuacja konfliktu wokół procesu sukcesji oraz napięć związanych z kierowaniem badaną firmą. Dla nestora najważniejszą wartość stanowiła niezależność:

(...) od najmłodszych lat miałem potrzebę bycia niezależnym, niezależność łączyłem także z niezależnością finansową (N1).

${ }^{54}$ P. Brzozowski, Przekazywanie wartości w rodzinie, „Psychologia Wychowawcza” 1988, nr 2, s. 190-199. Za: E. Jezierska-Wiejak, Rodzina jako międzypokoleniowa płaszczyzna transmisji wartości, „Wychowanie w Rodzinie” 2013, t. 8, nr 2, s. 296.

55 Por. H. Elżanowska: Międzypokoleniowa...; M. Ziemska, Postawy rodzicielskie, Wiedza Powszechna, Warszawa 2009. 
Wartość ta wyrażała się także w samym procesie sukcesji, zorganizowaniu struktury własności i kierowania w firmie. Mimo zakończenia procesu sukcesji i uporządkowania spraw majątkowych nestor zachował kontrolę nad firmą oraz większościowy udział w przedsiębiorstwie. Sukcesor natomiast w swoich działaniach dążył do takiego jej przekształcenia, aby nie musiał już nią kierować i poświęcać jej uwagi. Tym samym zmierzał do zyskania autonomii względem ojca, której brak mu doskwierał. Dlatego też, w przeciwieństwie do innych sukcesorów, rozwijał swoją alternatywną działalność biznesową. Podobieństwo wartości ujawniało się więc w praktyce, w dążeniu do uzyskania niezależności, choć nie było to wypowiadane wprost.

\section{Podsumowanie}

Zwrócenie uwagi na międzypokoleniową transmisję wartości pozwala na sproblematyzowanie, traktowanej jako naturalnej, zasady dziedziczenia pozycji. Sukcesorzy z firm rodzinnych stanowią wręcz modelowy przykład dziedziców, o których wspomina P. Bourdieu w swoich pismach. Uświadomienie sobie jednak, że tylko część dzieci z firm rodzinnych reprodukuje pozycję społeczną swoich rodziców, a jeszcze mniej faktycznie przejmuje biznes rodzinny, skłania do zastanowienia się nad mechanizmami tego dziedziczenia. Dziedziczenie wartości w procesie wychowawczym jest ważnym elementem zarówno reprodukcji struktury społecznej, jaki i trwałości oraz spoistości firm rodzinnych.

Próbując odpowiedzieć na pytanie o istnienie podobieństw i różnic pomiędzy wartościami nestorów i sukcesorów, można wskazać na podobieństwa w obszarze najwyżej cenionych wartości, najpowszechniej występujących w firmach rodzinnych. Jednocześnie habitusy nestorów i sukcesorów kształtowały się w odmiennych warunkach i tylko ci drudzy mogli w pełni doświadczyć spójności habitusów pierwotnych oraz wtórnych ${ }^{56}$. Dlatego też, analizując odpowiedzi w parach rodzic-dziecko, można dostrzec istotne zbieżności, a często dosłowne odwołania do tych samych wartości.

Rozróżnienie wartości rodzinnych i firmowych właściwie nie występuje $\mathrm{w}$ wypowiedziach respondentów, jednak istotnym czynnikiem modyfikującym jest napięcie pomiędzy wartościami uznawanymi w rodzinie biznesowej, a zwłaszcza pomiędzy znaczeniem rodziny jako wartości oraz pracy (firmy). Tym samym uzasadnione jest twierdzenie, że badani nie dokonują rozróżnienia wartości rodzinnych i firmowych, a przez to nie potrafią wskazać bezpośrednio

${ }^{56} \mathrm{~W}$ trzech przypadkach nestorzy wskazywali na znaczenie środowiska rodzinnego jako czynnika formującego ich chęć do założenia swojej własnej działalności gospodarczej, a w jednym z przypadków nestor odziedziczył firmę po swoim ojcu. 
ich różnic. Ujawnienie rozbieżności ról płciowych związanych z wychowywaniem dzieci wskazuje na potrzebę poszerzenia badań nad firmami rodzinnymi o żony-matki, które biorąc na siebie ciężar wychowawczy, miały znaczący wpływ na transmisję wartości. Wśród wypowiedzi odnoszących się do sytuacji konfliktowych, stabilizująca i scalająca rodzinę rola matki pojawiła się kilkukrotnie. Tym samym funkcja spójności pełniona przez rodzinę wiąże się z pozycją matki jako zaangażowanej w większym stopniu w życie rodzinne niż w firmę. Pytania o znaczenie matek dla powodzenia procesu sukcesji oraz przekazywania wartości w rodzinie wymagają jednak dalszych studiów. Biorąc pod uwagę ustalenia poczynione w toku badania, a także stwierdzone podobieństwo najważniejszych wartości wskazywanych przez nestorów i sukcesorów, można udzielić twierdzącej odpowiedzi na pytanie o transmisję wartości w rodzinach prowadzących własne firmy. Rodzina wskazywana była zgodnie przez nestorów i sukcesorów jako jedna z najważniejszych wartości, co stoi w sprzeczności z ustaleniami wcześniejszych badań wskazujących, iż idea rodzinności nie należy do priorytetowych wartości firm rodzinnych ${ }^{57}$.

\section{Bibliografia}

Barnach J., Granitsky J., Successful succession in family business, „Family Business Review” 1995, t. 8, nr 2, s. 131-155.

Bienert H., Eberhardt D., Hofmann R., Müller A., Entscheidungsprozesse in der Unternehmensnachfolge im Familienunternehmen - ein Prozessmodell, Forschungsbericht, KTI Nr 8555, 2008, https://digitalcollection.zhaw.ch/bitstream/11475/17110/2/Make\%20it\%20easier\%20to\%20 invest_2008_SC3.2.pdf (dostęp: 1.10.2021).

Bourdieu P., Szkic teorii praktyki. Poprzedzony trzema studiami na temat etnologii Kabylów, tłum. W. Kroker, Wydawnictwo Marek Derewiecki, Kęty 2007.

Bourdieu P., Passeron J.C., Reprodukcja. Elementy teorii systemu nauczania, tłum. E. Neyman, Wydawnictwo Naukowe PWN, Warszawa 2006.

Brzozowski P., Przekazywanie wartości w rodzinie „,Psychologia Wychowawcza” 1988, nr 2, s. 190-199.

Chua J., Christman J., Sharma P., Defining the Family Business by Behavior, „Entrepreneurship Theory and Practice" 1999, t. 23, nr 4, s. 19-39.

Churchill N., Hatten K., Non-Market-Based Transfers of Wealth and Power. A Research Framework for Family Businesses, „American Journal of Small Business” 1987, t. 11, nr 3, s. 51-64.

Creswell J.W., Projektowanie badań naukowych. Metody jakościowe, ilościowe i mieszane, tłum. J. Gilewicz, Wydawnictwo Uniwersytetu Jagiellońskiego, Kraków 2013.

Daily C., Thompson S., Ownerships Structure, Strategic Posture, and firm Growth. An Empirical Examination, „Family Business Review” 1994, t. 7, nr 3, s. 237-249.

Elżanowska H., Międzypokoleniowa transmisja wartości w rodzinie, w: Studia z Psychologii w Katolickim Uniwersytecie Lubelskim, t. 18, red. O. Gorbaniuk, B. Kostrubiec-Wojtachnio, D. Musiał, M. Wiechetek, Wydawnictwo KUL, Lublin 2012, s. 97-113.

Fleming Q.J., Tajniki przetrwania firmy rodzinnej, tłum. C. Matkowski, Helion, Gliwice 2006.

57 K. Safin, J. Pluta, B. Pabjan, Strategie sukcesyjne..., s. 121-123. 
Gomez-Mejia L.R., Haynes K., Nunez-Nickel M., Jacobson K., Moyano-Fuentes J., Socioemotional Wealth and Business Risks in Family Controlled Firms: Evidence from Spanish Olive Oil Mills, „Administrative Science Quarterly" 2007, t. 52, nr 1, s. 106-137.

Handler W., Methodological Issues and Considerations in Studying Family Business, , Journal of the Family Firm Institute" 1989, t. 2, nr 3, s. 257-276.

Jeżak J., Popczyk W., Winnicka-Popczyk A., Przedsiębiorstwo rodzinne. Funkcjonowanie i rozwój, Difin, Warszawa 2004.

Jezierska-Wiejak E., Rodzina jako międzypokoleniowa płaszczyzna transmisji wartości, ,Wychowanie w Rodzinie" 2013, t. 8, nr 2, s. 285-299.

Krajewska-Nieckarz M., Transfer wartości w procesie sukcesji firmy rodzinnej, „Przedsiębiorczość i Zarządzanie" 2016, t. 17, z. 6, s. 105-121.

Kvale S., Prowadzenie wywiadów, tłum. A. Dziuban, Wydawnictwo Naukowe PWN, Warszawa 2010. Łaciak B., Obyczajowość polska czasu transformacji, czyli wojna postu z karnawałem, Wydawnictwo Trio, Warszawa 2005.

Lamont M., Culture and Identity, w: Handbook of Sociological Theory, red. J.H. Turner, Kluwe Academia/Planum Publishers, New York 2001, s. 171-185.

Lamont M., Money, Morals and Manners. The Culture of the French and American Upper-Middle Class, The University of Chicago Press, Chicago-London 1992.

Lamont M., The Dignity of Working Man. Morality and the Boundaries of Race, Class and Immigration, Russell Sage Foundation, New York 2000.

Lewandowska A., Identyfikacja kluczowych wartości jako istotny element konkurowania firm rodzinnych, w: Zarządzanie w XXI wieku. Koncepcje, trendy, problemy, red. B. Godziszewski, B. Kołosowska, J. Szołno-Koguc, Wyższa Szkoła Bankowa, Toruń 2009, s. 177-186.

Lewandowska A., Lipiec J., Konstytucje firm rodzinnych. W kierunku długowieczności, Oficyna a Wolters Kluwer business, Warszawa 2015.

Lewandowska A., Kody wartości czyli jak skutecznie przejść sukcesję w firmie rodzinnej, Lewandowska i Partnerzy, Poznań 2015.

Maciel A.S., de la Garza Ramos M.I., Esparza Aguilar J.L., San Martin Reyna J.M., The Influence of Family Relationships in the Succession, „Journal of Family Business Management” 2015, t. 5, nr 2, s. 238-256.

Marjański A., Specyfika firm rodzinnych, w: Firma w rodzinie, czy rodzina w firmie. Metodologia wsparcia firm rodzinnych, Polska Agencja Rozwoju przedsiębiorczości, Warszawa 2012, s. 30-38.

Miller E., Rice A., Systems and Organizations, Tavistock Publications, London 1967.

Misztal M., Problematyka wartości w socjologii, PWN, Warszawa 1980.

Ostruch-Kamińska J., „Choroba wiecznego prymusa” - rozważania wokół znaczenia pracy zawodowej w rodzinie o równoległych karierach, w: Rodzina w świecie wartości. Religia, praca i czas wolny, red. W. Muszyński, Wydawnictwo Adam Marszałek Toruń 2010, s. 264-265.

Pawlak A., Sukcesja w polskich przedsiębiorstwach rodzinnych, „Przedsiębiorczość i Zarządzanie” 2014, t. 15, nr 7 (1), s. 55-67.

Safin K., Pluta J., Pabjan B., Strategie sukcesyjne polskich przedsiębiorstw rodzinnych, Difin, Warszawa 2014.

Sharma P., Christman J., Chua J., Strategic Management of the Family Business. Past Research and Future Challenges, „Family Business Review” 1997, t. 10, nr 1, s. 1-35.

Skrzypniak R., Transmisja międzypokoleniowa wartości wychowawczych w rodzinie, Rodzina w czasach szybkich przemian, „Roczniki Socjologii Rodziny" 2001, t. 13, s. 149-160.

Slany K., Alternatywne formy życia małżeńsko-rodzinnego w ponowoczesnym świecie, Zakład Wydawniczy Nomos, Kraków 2003.

Strykowska M., Psychologiczne mechanizmy zawodowego funkcjonowania kobiet, Wydawnictwo Naukowe UAM, Poznań 1992.

Suchocka A., Przemoc symboliczna jako element ukrytego programu kształcenia polskiej szkoły, „Zeszyty Naukowe Akademii Marynarki Wojennej” 2011, R. 52, nr 4 (187), s. 293-302. 
Sułkowski Ł., Marjański A., Firmy rodzinne. Jak osiągnąć sukces w sztafecie pokoleń, Wydawnictwo Poltext, Warszawa 2009.

Sułkowski Ł., Organizacja a rodzina. Więzi rodzinne w życiu gospodarczym, TNOiK „Dom Organizatora", Toruń 2004.

Surdej A., Wach K., Przedsiębiorstwa rodzinne wobec wyzwań sukcesji, Difin, Warszawa 2010.

Szymczyk J., Socjologiczne rozumienie wartości w aspekcie relacjonistycznym, "Zeszyty Naukowe KUL" 2019, t. 62, nr 3, s. 35-54.

Venter E., Boshoff C., Maas G., The Influence of Successor Related Factors on the Succession Process in Small and Medium Sized Family Businesses, „Family Business Review” 2005, t. 18, nr 4, s. 283-303.

Walęcka-Matyja K., Rola i funkcje rodziny, w: Psychologia rodziny, red. I. Janicka, H. Liberska, Wydawnictwo Naukowe PWN, Warszawa 2014, s. 95-114.

Ward J., The special role of straitening planning for family businesses, „Family Business Review” 1988 , t. 1, nr 2, s. 105-117.

Więcek-Janka E., Wiodące wartości w zarządzaniu przedsiębiorstwami rodzinnymi, Wydawnictwo Politechniki Poznańskiej, Poznań 2013.

Zajkowski R., Transfery władzy, własności i wartości w przedsiębiorstwach rodzinnych. Efekt drugiego pokolenia, Wydawnictwo C.H. Beck, Warszawa 2018.

Ziemska M., Postawy rodzicielskie, Wiedza Powszechna, Warszawa 2009.

Ziółkowski M., Znaczenie, interakcja, rozumienie. Studium z symbolicznego interakcjonizmu i socjologii fenomenologicznej jako wersji socjologii humanistycznej, PWN, Warszawa 1981.

\section{Streszczenie}

Rodzina, jako grupa pierwotna, stanowi w życiu człowieka naturalną domenę wychowania. Rodzice mają ogromny wpływ na kształtowanie się ram poznawczych, przekonań i postaw moralnych swoich dzieci, przygotowują je do pełnienia różnorodnych ról społecznych oraz budowania własnej tożsamości. Wartości są traktowane jako cecha wyróżniająca firmy rodzinne na tle innych przedsiębiorstw, a międzypokoleniowa transmisja wartości staje się mechanizmem, który pozwala na ciągłość pokoleniową i trwałą tożsamość firmy. Artykuł jest poświęcony problematyce wartości w kontekście przygotowania sukcesorów do objęcia pozycji kierowniczych i właścicielskich w firmach rodzinnych. Podstawę teoretyczną stanowi teoria Pierre’a Bourdieu i koncepcja granic symbolicznych Michèle Lamont. Artykuł przedstawia wyniki badań jakościowych zrealizowanych w firmach rodzinnych, które przeszły proces sukcesji. Wywiady zostały przeprowadzone zarówno z nestorami, jak i sukcesorami, co umożliwia porównanie perspektyw obu pokoleń.

Słowa kluczowe: transmisja wartości, firma rodzinna, sukcesja, rodzina, praca

\section{The Intergenerational Transmission of Values in Family Businesses} in the Context of Business Succession

\section{Summary}

Family, a primary group, is a natural domain of upbringing in human life. Parents have tremendous influence on the formation of the cognitive framework, beliefs and moral attitudes of their children. They educate them to fulfil various social roles and build their own identity. Values constitute a feature that distinguishes family businesses from other enterprises, and the intergenerational transmission of values becomes a mechanism that allows for generational continuity, leading to a permanent identity of the company. The article is devoted to the problem of values in the context of preparing successors 
to take managerial and ownership positions in family businesses. The article is anchored theoretically in Pierre Bourdieu's research position, as well as the concept of symbolic boundaries by Michele Lamont. The article discusses the results of qualitative research carried out in family businesses under succession process. The interviews were conducted with both senior managers and their successors, which enable an effective comparison of the perspectives unveiled by both generations.

Key words: transmission of values, family business, business succession, family, work 
